\title{
Hybrid transnational advocacy networks in environmental protection: banning the use of cyanide in European gold mining
}

\author{
Alexandra-Maria Bocse ${ }^{1}$ (D)
}

Accepted: 24 June 2020 / Published online: 10 July 2020

(c) The Author(s) 2020

\begin{abstract}
This paper contributes theoretically, empirically and methodologically to the literature on transnational advocacy networks (TANs). This study is guided by two associated research questions: 'How are TANs structured?' and 'What relation is established between the TANs' structure and their efficiency?' The paper shows that environmental transnational advocacy networks are not as horizontal as assumed in the TANs literature. Elements of hierarchy are present in networks through highly connected and/or strategically positioned nodes. This paper shows that elements of hierarchy are introduced in networks to facilitate information exchange and decision-making. The paper studies for the first time the TAN advocating the ban of cyanide-based mining in Europe in the late 2000s-early 2010s. The network aimed to impact the EU environmental legislative framework, as well as contribute to the implementation of international agreements on pollution prevention and biodiversity protection. This study draws on extensive fieldwork (including interviews with forty-five members of the network) conducted in several European countries in which the network developed and maintains branches. The study innovates methodologically by combining content analysis and social network analysis in the process of determining the more central actors of the network studied.
\end{abstract}

Keywords Transnational advocacy networks · Hybrids · Gold mining · European Union · Social network analysis

\section{Introduction}

The proliferation of transnational networks led to an increasing interest among international relations scholars in investigating their role in world politics (Castells 1996; Keck and Sikkink 1998; Betsill and Bulkeley 2004; Kahler 2009a; Yanacopulos 2009). Although progress has been achieved recently in documenting transnational networks, the way these networks form, their structure, the way they operate and the degree to which they impact on

Alexandra-Maria Bocse

a.bocse@1se.ac.uk; alexandra.maria.bocse@gmail.com

1 Fellow in International Relations, London School of Economics and Political Science, Houghton Street, London WC2A 2AE, UK 
world governance remain matters of debate (Betsill and Bulkeley 2004; Kahler 2009a; Eilstrup-Sangiovanni 2009; Maoz 2012). Particularly, the analysis of the relationship between the networks' structure and the way they function is underexplored in the literature. This study is guided by two associated research questions: 'How are TANs structured?' and 'What relation is established between the TANs' structure and their efficiency?'

While the networks' success is typically considered to be based on their horizontal structure, this paper offers insight into the hierarchy accommodated by transnational advocacy networks in order to improve their performance. The paper finds that claims related to the presence of hierarchy in networks made by Carpenter (2011) and Lake and Wong (2009) in relation to security and, respectively, human rights networks are valid also for environmental transnational advocacy networks.

In the last two decades, we witnessed the proliferation of literature that analyzes the role that transnational networks can play as promoters of international norms and standards (environmental, labor, human rights, etc.) (starting with the seminal work of Keck and Sikkink 1998). Most of this literature is qualitative, very few studies provide us with network maps, and very few systematically analyze the relations established among the network members. Although this study also draws heavily on a qualitative methodology, it supplements its findings with social network analysis (SNA) that is also useful in the process of generating network maps. Very often the Politics and International Studies literature is limited to using the concept of 'network' as a metaphor. The 'network society' (Castells 1996) is a concept that has benefited from a lot of interest from both academia and media. The data collected for this study, in depth and in a systematic manner, capture a section of this 'network society' and contribute to grounding empirically the network metaphor that in recent years has occupied a central place in the process of theorizing about contemporary society and politics.

This research studies the case of a Central and Eastern European (CEE) transnational advocacy network calling for the banning of cyanide-based mining in several EU countries and then in the whole EU, given its potential to harm the environment. This informal social structure will be referred to as the cyanide ban network (CBN). During its EU-wide campaign, the CBN advocated for 'a general ban on the use of cyanide mining technologies in the European Union' (The European Parliament 2010, 1). The ban was framed by its supporters as being demanded by the 'precautionary principle, as set out in the Rio Declaration on Environment and Development and in the Convention on Biological Diversity adopted in Rio de Janeiro' (Ader et al. 2010, 2). The CBN referred to cyanide as being a very toxic chemical whose use comes with a high risk of harming the environment, polluting waters and negatively impacting biodiversity. To illustrate their arguments, advocates pointed to previous cases of water contamination and biodiversity damage happening in the CEE. For example, the 30 January 2000 cyanide spill at a gold and silver production plant in Baia Mare (Northwestern Romania) brought irreversible damage to the biodiversity of the Tisza River and affected the quality of water in the Danube (The UN Environmental Program/The UN Office for the Coordination of Humanitarian Affairs 2000). The EU ban was also presented by the network as contributing to the implementation of the 1994 Sofia Convention on Cooperation for the Protection and Sustainable Use of the River Danube. The convention is targeted at preventing transboundary pollution and, among others, pollution originating in the mining sector.

A transnational advocacy network is defined as a set of: 'relevant actors working internationally on an issue, who are bound together by shared values, a common discourse, and a dense exchange of information and services' (Keck and Sikkink 1998, 2). TANs are transnational networks 'organized to promote causes, principled ideas and norms, and they 
often involve individuals advocating policy changes that cannot be easily linked to a rationalist understanding of their interests' (Keck and Sikkink 1998, 9). In the case of TANs, the factors that motivate action are the intellectual and emotional dedication of the participants (Rodrigues 2004). Throughout the paper, the TAN actors will be referred to more broadly as activists or advocates.

The classification of the social structure working toward the ban of cyanide-based mining as a TAN is based on the data collected and the analysis conducted by the author of this study. It is also a term that most of the actors operating in this network found to capture well their relationships (as indicated by the interviews with several network members: EAH5, EAB2, EAG1, EAG3, EAR2 ${ }^{1}$ ). In the process of classifying the social structure discussed in the article as a TAN, alternative concepts such as 'advocacy coalition' or 'lobby group' were contemplated, but they turned out to be less able to capture the social reality uncovered through fieldwork on this case study.

Advocacy networks emerge around environmental and human rights concerns, areas that are traditionally related to the field of 'low politics,' but also in relation to areas that present an important stake for state and global security, associated with 'high politics' (Price 1998; Carpenter 2011; Carpenter and Jose 2012). Environmental concerns are quite likely to generate transnational networked action. Cross-border pollution, ecological interdependence and the need to properly manage the global commons have motivated both public and private actors to act across national boundaries (Held et al. 1999; Mason 2001). Environmental TANs have emerged, for example, around efforts to stop tropical deforestation in the Brazilian Amazon (the Planafloro and Polonoroeste campaigns) or in the Malaysian state of Sarawak (Keck and Sikkink 1998), as well as around the struggle against the construction of dams and power plants that pose environmental threats in Southeast Asia (Rumansara 2000; Royo 2000; Rodrigues 2004).

The cyanide ban network is a case well worth investigating for several reasons. First, it depicts the emergence of a transnational advocacy network based in Central and Eastern Europe, a region where the environmental civil society has been previously considered weak (Howard 2003; Welch 2004; Romantan 2006; Buzogány 2009). This way, the study also contributes to the rather scarce literature on civil society in post-communist Europe (exceptions being Howard 2003; Parau 2009; Ekiert and Kubik 2014; Cox and Gallai 2014; Torsello 2016). Second, the study represents a valuable empirical contribution to the TAN literature being the first to analyze the cyanide ban opposition in Central and Eastern Europe in the TAN framework. In this way, the paper aims to respond to the need to expand the set of case studies on international networks and particularly transnational advocacy networks (Kahler 2009a; Carpenter 2011). Third, and most important, this case allows for the study of hybrid networks operating in environmental advocacy. As it will be shown in more detail later, elements of centralization are included in the structure of the otherwise flat network to improve information exchange and decision-making in the network.

The paper begins by introducing the theoretical framework and research design adopted by this study. The second section introduces the CBN and the context of its emergence. The third section brings both qualitative and quantitative evidence in support of the CBN's hierarchical social structure, revealing network hubs defined as nodes ${ }^{2}$ that are well

\footnotetext{
1 Please see the bibliography for an explanation of the abbreviations.

2 'Node' is the concept used in social network analysis to refer to the network 'members,' 'participants,' 'activists,' 'advocates.' These concepts will be used interchangeable in the text, with the concept of 'node' being used mainly in the section dedicated to social network analysis.
} 
connected in the network (Kahler 2009b). The fourth section provides insight into the factors that led to the emergence of hubs. Although the horizontality of networks is usually considered to be a positive feature, the paper shows that a certain degree of hierarchy is introduced by the network members to facilitate communication and decision-making in the TAN. The concluding part of the paper makes some final remarks and points toward new avenues for research.

\section{Theoretical framework and research design}

Scholars argue the concept of 'network' is well suited in accommodating a diversity of actors (Witte et al. 2005), of relative equal standing and loosely connected (Zanini and Edwards 2001). Horizontality is considered a central defining feature of the network form of organization. According to an influential study on TANs, networks are 'forms of organization characterized by voluntary, reciprocal and horizontal patterns of communication and exchange' (Keck and Sikkink 1998, 8). The accommodation of hierarchical features in advocacy networks started to be acknowledged by the literature with the work of Bob (2005), Lake and Wong (2009) and Carpenter (2011). The work of Carpenter (2011) and Lake and Wong (2009) discusses network hubs and hierarchy in relation to security and human rights networks. This study aims to contribute to the literature acknowledging that TANs present elements of hierarchy in their structure by detecting and studying hierarchy in an environmental network. It also discusses the factors that led to the inclusion of hierarchy in the structure of the network.

Networks are contrasted with the hierarchies that characterize state organization, on the one hand, and the temporary relations typical of markets, on the other hand (Powell 1990; Thompson 2003; Kahler 2009a). Networks are thought to have a series of organizational advantages over hierarchies given their horizontality: facilitation of communication and information exchange (Powell 1990; Baker and Faulkner 1993; Podolny and Page 1998), adaptability to contextual changes (Thompson 2003; Kenney et al. 2013) and increased learning capacity (Keck and Sikkink 1998; Kenney 2006; Kenney et al. 2013).

The CBN was set up to exchange information and allow different segments of the network to learn from each other in their campaigning work. In a hierarchical structure, information often needs to pass through a central unit, causing possible communication delays. Proponents of networks claim that the flat structure of networks allows for rapid information exchange between central and peripheral nodes (Watts 2003; Powell 1990). The network form of organization is also thought to be superior in fostering learning (Powell 1990; Uzzi 1997; Podolny and Page 1998). Learning takes place when the members of an organization accumulate, analyze and act on new data which may lead to the change of individual and network practices (Levitt and March 1988; Kenney 2007, 2009; Kenney et al. 2013). Networks facilitate learning for several reasons. First, the network links act as effective communication channels that allow for the spread of good practice from one node to another (Hamel 1991). Second, as shown by Powell and Brantley (1992), networks foster learning by facilitating the synthesis of new information, distinct from the data initially possessed by different network nodes. The stable and sustained exchange generates new knowledge, and in this way the network, rather than the nodes that comprise the network, becomes a space of innovation (Podolny and Page 1998).

However, there is also literature on networks indicating that the lack of hierarchy can make networks poor information transmitters and learning spaces (Powell 1990; Thompson 
2003; Eilstrup-Sangiovanni and Jones 2008; Eilstrup-Sangiovanni 2009). The search for information in networks that are decentralized can be difficult and the lack of organizational memory administered by designated authorities impedes effective learning. Networks can also display poor and slow decision-making as virtually all network members are involved in the decision-making process (Eilstrup-Sangiovanni and Jones 2008). Introducing elements of hierarchy in the network structure can overcome some of the shortcomings of decentralized, horizontal structures with equal members. The literature on terrorist networks indicates that centralization is crucial in conducting sophisticated terrorist attacks (Helfstein 2009; Enders and Su 2007). The study on terror networks undertaken by Ender and Jindapon shows that more centralized networks are better at mobilizing their members, members are better connected and more able to respond to change (Enders and Jindapon 2009).

To address some of the shortcomings of decentralization, hybrids emerge by 'combining constituents that are networked with those that resemble hierarchies or markets' (HafnerBurton et al. 2009, 582). Hybrids are defined as:

networks that include hierarchies among their nodes or networks with nodes that wield power within the network through centrality or other structural characteristics. A network with relatively few well-connected nodes (hubs) may introduce hierarchy into the 'flatness' and apparent egalitarianism of network spaces (Kahler 2009b, 106).

In a network, there might or might not be formal recognition of the de facto hierarchy that characterizes the network: 'in a highly centralized network with a few hubs that are linked to most of the other nodes, authority may inhere to position, without formal recognition' (Kahler 2009b, 112).

Well-connected nodes tend to occupy a more central position in the network and have more relational power. If in the power as currency/attributional power approach the power of each actor is dependent on the possession of weapons, financial resources, personnel, etc., the relational approach to power argues the actor's position in the network shapes its power to influence decision-making (Krahmann 2003b). The concept of relational power rejects attempts to explain human behavior as caused only by the categorical attributes of individual or collective actors and generates explanations that are based on the involvement of actors in structured social relations (Emirbayer and Goodwin 1994, 1414). This study responds to calls in literature to move beyond identity-based explanations of social action and embrace explanations drawing on: 'commonality, connectedness, and groupness' (Brubaker and Cooper 2000, 20).

Brokers are a particular type of well-connected nodes (or hubs) and tend to possess substantial relational power. Brokers reduce the 'network segmentation' (Diani 2003). Several scholars wrote on the power that brokers possess given their ability to connect actors or network segments that would remain disconnected in their absence. Such studies cover transnational activist networks (Carpenter 2011), terrorist networks (Enders and Su 2007) or state networks (Hafner-Burton et al. 2009). Brokers 'facilitate information sharing - and learning - throughout the network as they pass along knowledge and other resources to less well-connected agents' (Kenney et al. 2013, p. 740). Brokers have a privileged position in policy subsystems and policy networks they are part of.

The investigation of the structure of the cyanide ban network and of the factors that generate its hybridity was conducted through participant observation and semi-structured interviews with forty-five members of the CBN, twenty-two of which are explicitly referenced in this paper. Semi-structured interviews are suitable for studying the structure and 
dynamics of still underexplored social structures, such as TANs. They allow for the discovery of new facts and patterns, while making sure the data gathered are comparable (Gillham 2005).

Interviews were conducted between August 2010 and April 2011. The interviewees include a wide variety of actors, from representatives of non-governmental organizations (NGOs) to scientists, from members of local movements to high governmental officials or Members of the European Parliament (MEPs) located in Romania, Hungary, Bulgaria, Greece and Belgium. Preference was given to face-to-face interviewing whenever possible. During face-to-face interviewing, the 'rapport,' defined as the mutual reading of the presentation of self between the interviewer and interviewee (Fontana and Frey 1994), was easily created and this led to a high degree of disclosure. Six interviews were conducted online through a videoconferencing platform (Skype). Given that the interviewees were environmental activists who use this platform daily, the level of disclosure was similar to the one in face-to-face interviews.

In selecting the interviewees, as a first step, I generated an initial list of potential interviewees by relying on publicly available information (documents, websites and newspaper articles). The initial list was gradually expanded using names mentioned by the network members during the interviews. This procedure is known in the literature as the snowball technique: 'the technique of building an exponentially increasing network of research subjects from an original subject zero' (Gusterson 2008, 98). Clearly defining the boundaries of social networks can be challenging. By allowing the author of this study to access the network sample gradually, the snowball technique allowed for capturing the network boundaries (Goodman 1961; Wasserman and Faust 1994). Interviewing stopped when 'saturation' (as defined by Burnham et al. 2008) was reached, that is, when no new additional data emerged through interviewing and the data gathered allowed for an in-depth understanding of the network structure and dynamics.

As part of the interview process, network members were asked: 'Who did you cooperate with in the campaign to ban cyanide in gold mining in the EU?' The connections between the network members reported in the answers were analyzed using social network analysis. Social network analysis allows for measuring, mapping and analyzing contacts among a group of actors (or 'nodes'), which may be human or nonhuman (John and Cole 1998). The network actors and the links between them are illustrated in this paper through graphical displays, called sociograms (Wasserman and Faust 1994; John and Cole 1998). The analysis was conducted at the level of individuals, not organizations. Two actors were considered connected if at least one of them provided the other with information and/or campaigning advice. Data were recorded in an Excel spreadsheet and SNA was performed using NodeXL. The sociograms included in this paper were also generated with NodeXL.

This study uses two centrality measures to identify nodes that are central to the network, the hubs: 'degree centrality' and 'betweenness centrality,' both computed with NodeXL. Degree centrality refers to the number of connections ${ }^{3}$ a node of the network has with other nodes, a high number implying a high degree centrality (John and Cole 1998). This research will follow Freeman (1979) and Goddard (2009) and will look at the measure of betweenness centrality to identify the brokers in the network (Goddard 2009). A high betweenness centrality is generated by the position of the actor as a connector between different sections of the network (John and Cole 1998, Gulati et al. 2002). The computing of

3 The concepts 'connection' and 'link' between nodes are used interchangeably in this study. 
the two centrality measures allowed to determine the presence of central actors in the CBN. Before moving to discussing these central actors and the implication of their presence for the structure of the $\mathrm{CBN}$, the paper will briefly introduce the network, its formation process and membership.

\section{The cyanide ban network}

Gold mining led in the late 2000s to public controversy in several Central and Eastern European (CEE) countries, as multinational mining companies expressed an interest in developing gold mining projects. Some of the projects were located in areas where gold was previously extracted in underground mining facilities run by state-owned companies (Richards 2005; Damigos and Kaliampakos 2006). Gold reserves in these regions were reduced and mining was found to be unprofitable by governments, so mines were closed. However, a few years later the steady increase in the price of gold (Bank of England 2011) and the development of more advanced gold extraction technology made it profitable for multinationals to mine the gold. The proposed technology for mining gold is cyanide leaching, a procedure that implies the dislocation of the rock bearing gold, the ore and its treatment with sodium cyanide acting as a magnate attracting the precious metal. The cyanide resulting from gold processing is stored in large tailings ponds.

Although there was an agreement between many of the EU governments and the European Union that cyanide leaching is the best available gold extraction technology from an environmental point of view (The European Commission 2010), this method was deemed by certain scientists, NGOs and local movements as posing high environmental risks (Buza et al. 2001). Advocates of a cyanide ban pointed to the devastating accidents associated with cyanide-based mining that took place in CEE countries and worldwide in previous years. In addition to the environmental damage, open cast cyanide-based mining projects often implied the dislocation of local inhabitants from several settlements in CEE countries and Greece (Damigos and Kaliampakos 2006; Richards 2005).

The opposition to this type of mining technology took the form of a transnational advocacy network. The CBN emerged as a social structure around a series of campaigns to ban cyanide-based mining. Campaigns to ban cyanide-based mining took place in Romania (starting in 2007), Bulgaria (starting in 2008), Hungary (starting in 2009), Greece (starting in 2010). Although they appear to be national in scope, each of these campaigns involved also foreign activists that contributed to the campaign mainly with information and advice. In this way, the network acquired a strong international dimension.

The Romanian campaign to ban cyanide-based mining started in 2007. The campaign was led by a NGO coalition and the legislative proposal had the strong backing of two Senators in the Romanian Parliament (EAR6). After a series of initial successes registered by the campaigners, the industrial counter-lobby managed to reach the Industry Committee of the Lower Chamber in the Romanian Parliament and blocked the ban legislation adoption procedure ${ }^{4}$ (EAR6, EAR8). A campaign for banning cyanide-based mining began in Bulgaria in 2008, inspired by the Romanian campaign (EAR1, EAB2). A legislative proposal to ban cyanide in Bulgaria was drafted by the NGOs and tabled by the leader of

\footnotetext{
${ }^{4}$ On April 15, 2008, the Romanian cyanide ban bill, after being debated by the Chamber of Deputies, was sent back to the Industry Commission of the Chamber for a second examination. There the process of achieving the ban was blocked.
} 
the Bulgarian right-wing Unified People's Party (EAB3). The proposal was supported by a coalition of domestic NGOs and local social movements. The approx. 14,000 signatures collected in the autumn of 2008 in favor of the ban of cyanide in gold mining were submitted to the National Parliament as proof of the public support for the ban (EAB1, EAB3). However, the legislative proposal was eventually rejected with a 15 -vote difference, in a 240-seat Assembly.

The failure of the campaigns in Romania and Bulgaria triggered the Hungarian campaign to nationally ban cyanide-based mining in 2009. The environmental activists in Hungary aimed to set a ban example in Central and Eastern Europe rather than deal with immediate domestic cyanide threats (EAH1, EAH4). They hoped that other countries in the region will follow in adopting a ban. The mining projects that worried first and foremost the Hungarian activists were the ones in neighboring Romania (EAH1, EAH4, EAH3, EAH5). On December 7, 2009, the prohibition of the use of cyanide-based technology in mining in Hungary was almost unanimously voted by the Hungarian Parliament. The successful Hungarian campaign inspired activists in Greece, where opposition to different gold mining projects had been persistent for over a decade (EAG1). The initiative to ban cyanide in Greece came from the academics at the University of Thessaloniki and not from the NGOs, as in the cases of Romania, Bulgaria and Hungary. In January-February 2010, around 300 signatures for a cyanide ban were collected from academics and students affiliated with the University of Thessaloniki and, although initially gathered to be submitted to national authorities, they were sent to the European Parliament (EAG1, EAG2).

The network reinforced its international dimension, especially during the campaign to ban cyanide-based mining in the entire European Union reaching a peak on May 5, 2010 (the day when the European Parliament passed a Resolution demanding a ban on the use of cyanide-based mining technologies in the European Union). Having achieved a Hungarian ban, the Budapest-based NGOs took the initiative of an EU level campaign by contacting Hungarian MEPs (EAH1) and captured particularly the attention of a Hungarian MEP, member of the European Parliament's Committee on Environment, Public Health and Food Safety. This MEP was soon joined by other MEPs, mainly from Hungary, Romania, Greece, Bulgaria, in drafting a resolution demanding a ban on the use of cyanide-based mining technologies in the EU before the end of 2011. The MEPs were lobbied by NGOs and social movements in CEE. The latter were also successful in mobilizing the Group of the Greens in the EP. On the day of the vote, May 5, 2010, the resolution passed with 448 votes in favor, 48 against and 57 abstentions. Afterward, advocacy shifted to the European Commission in the attempt to turn the EP resolution into EU legislation.

The EU-wide campaign consolidated a TAN including, at its peak, in May 2010: representatives of domestic NGOs, representatives of international non-governmental organizations (INGOs), international environmental activists, politicians (MPs and MEPs), high governmental officials, scientists, representatives and volunteers of local social movements. ${ }^{5}$ As will be shown in the next section, some network members are more central to the network than others generating hierarchy in the CBN.

\footnotetext{
${ }^{5}$ It is often difficult to place a certain network member in a single category. In the CBN, there are situations when a volunteer in a local movement is also an NGO employee, a scientist is also a member of a local movement, or an individual is associated with an INGO and a domestic NGO. For social network analysis purposes, their primary affiliation was used.
} 


\section{Hubs in the cyanide ban network}

In identifying the existence of hubs in the network and who these hubs are, this paper triangulated the description that interviewees gave on how the network is structured with the social network analysis (SNA) performed on the connections reported by the network members. Those connections facilitated the exchange of information and best practice leading to learning. This study will not discuss exchanges of financial resources, as the data collected did not find them to be as important as information exchanges in the work of the network. Both the qualitative interview data and the SNA indicate that certain network members are more central and influential in the network.

The interviewees indicated in their network description that the $\mathrm{CBN}$ has a 'nerve center' that consists of eleven persons. They stay connected through emailing, telephoning and the presence in a closed online group. People that constitute the nerve center work in the environmental protection field for a domestic or international NGO or are leaders of local movements that oppose the use of cyanide in specific mining projects. They acted as connectors between the campaigning groups based in several countries. These actors kept the communication alive across national boundaries. As discussed in the next paragraphs, at the same time the 'nerve center' kept connected segments of the network fulfilling certain specialized functions: providing information and legitimacy in the case of social movements, scientific evidence in the case of scientists and politically relevant information in the case of politicians.

Local social movements are connected to the international network through activists and representatives of NGOs in the case of the Romanian movement and through local leaders in the case of the movements based in Greece. The local movement in Bulgaria is connected to the international network through several INGOs and NGOs representatives. These connectors are part of the network's 'nerve center.' Although less central to the CBN activity, local social movements are an important source of information and legitimacy for the actors at the core of the network (EAR2, EAR8, MEPA1, MEPA3).

The representatives of NGOs and INGOs in the 'nerve center' and demanding a cyanide ban based their arguments presented to politicians and to the public on scientific reports and information generated by scientists. In this regard, they acted as information brokers between scientists and politicians. The scientists opposing cyanide-based mining are connected across borders mainly through NGOs and INGOs representatives (EAH1, EAB1). Some of the scientists whose work is referenced in the cyanide ban campaigns briefs are old acquaintances of the NGOs and INGOs representatives at the very core of the cyanide ban campaigns (EAR3, EAG2, EAG3, interview with the President of the Romanian Academy).

In addition to NGOs and INGOs representatives in the 'nerve center,' in the case of the $\mathrm{CBN}$ an important role in maintaining the connection between activists physically located in Central and Eastern Europe and the Brussels-based political arena was played by a MEP assistant, working with the Hungarian MEP who initiated legislation demanding the banning of cyanide-based mining in the EU. Depending on their involvement in campaigns, politicians are more or less central to the network, but usually they rely on their staff to mediate the communication and information exchanges with the rest of the network. When asked about their cooperation with the Members of the European Parliament on achieving an EU-wide cyanide-based mining ban, a member central to the network indicated the two types of relationships that are established with politicians: 
there are two different levels, we have allies, whom we are working with, and we have supporters, who are kind of sympathetic to our cause [...] The second category [the supporters]: we give them information, we update them about the case, but there are some MEPs with whom we have a closer connection [the allies]. We give them important material to speed up the process and sometimes they give us some information and we embark in some action that is important to reach our common goals (EAH3).

The qualitative findings on the presence of hubs in the CBN were confirmed also by the SNA performed on the network. The eleven actors the interviewees indicated are part of the 'nerve center' scored high in terms of both degree and betweenness centrality. Eight scored within the top ten degree centrality values and seven scored within the top ten betweenness centrality values. These actors are better connected with the other network actors, and these connections are also strategically more important for the information and good campaigning practice flows in the network. I start by introducing the degree centrality scores: (Table 1, Fig. 1)

Table 1 Degree centrality

\begin{tabular}{llll}
\hline Node & $\begin{array}{l}\text { Degree cen- } \\
\text { trality }\end{array}$ & Shape & Color \\
\hline MEPA1, MEP assistant & 34 & Solid square & Red \\
EAH3, Representative of 'Greenpeace' Hungary & 29 & Solid square & Red \\
EAH1, Representative of 'Friends of the Earth' Hungary & 25 & Solid square & Red \\
EAR1, Representative of a Romanian social movement & 24 & Solid square & Red \\
EAH2, Representative of 'Bankwatch' Hungary & 24 & Solid square & Red \\
EAR3, Representative of a Romanian environmental NGO & 23 & Solid square & Red \\
EAR2, Representative of a Romanian environmental NGO & 20 & Solid square & Red \\
EAH4, Member of the Green Hungarian Party LMP, Member & 16 & Solid square & Red \\
of the Hungarian Parliament & & Solid square & Black \\
EAR6, Representative of a Romanian environmental NGO & 8 & Solid square & Black \\
EAH5, Volunteer at a Hungarian environmental NGO & 8 & &
\end{tabular}

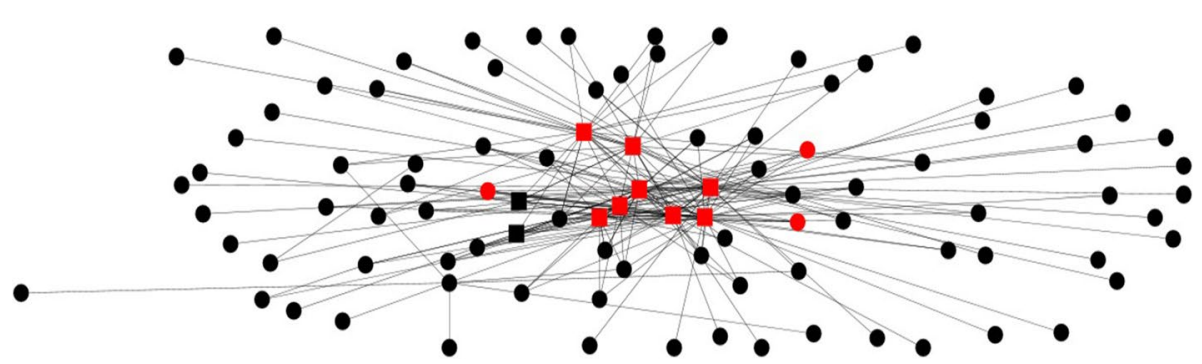

Fig. 1 Sociogram showcasing nodes with high degree centrality (The sociograms in Figs. 1 and 2 are a snapshot of the network as of 5 May 2010 reconstructed through SNA based on data collected through interviews (forty-five people were interviewed revealing connections with a larger number of entities). On that day, the European cyanide ban campaign reached its peak as the European Parliament passed the Resolution demanding a ban on the use of cyanide mining technologies in the European Union). Solid squaretop 10 degree centrality. Disk-rest of the nodes. Red-nodes identified as central by the qualitative data. Black-rest of the nodes 
Nodes that appear on the figure as solid squares are the ten nodes with the highest degree centrality. Degree centrality for these nodes ranges from 34 (for a node connected with other 34 nodes) to 8 (for a node connected with other 8 nodes) (Table 1). The node with the highest degree centrality is the assistant of the Member of the European Parliament that initiated legislation banning cyanide-based mining at the EU level. One node is a Member of the Green Hungarian Party LMP and also a Member of the Hungarian Parliament. The other eight are representatives of INGOs, NGOs and social movements.

One of the problems with degree centrality is that it might just capture one's belonging to a dense subgroup and not a node's reach across the whole network (Mérand et al. 2011). Nodes belonging to the same national CBN segment are strongly connected with each other, which boosts a node's centrality score, although that node might not hold important international connections. To help remedy this problem, the paper also looks at betweenness centrality scores (Table 2, Fig. 2).

Table 2 Betweenness centrality

\begin{tabular}{llll}
\hline Node & $\begin{array}{l}\text { Betweenness } \\
\text { centrality }\end{array}$ & Shape & Color \\
\hline MEPA1, MEP assistant & 2152.586 & Solid triangle & Red \\
EAR1, Representative of a Romanian social movement & 948.179 & Solid triangle & Red \\
EAH3, Representative of 'Greenpeace' Hungary & 754.040 & Solid triangle & Red \\
EAR2, Representative of a Romanian environmental NGO & 732.742 & Solid triangle & Red \\
EAR3, Representative of a Romanian environmental NGO & 698.979 & Solid triangle & Red \\
EAH2, Representative of 'Bankwatch' Hungary & 599.367 & Solid triangle & Red \\
EAH1, Representative of 'Friends of the Earth' Hungary & 592.473 & Solid triangle & Red \\
EAR6, Representative of a Romanian environmental NGO & 372.323 & Solid triangle & Black \\
AMBH, The Hungarian Ambassador to Romania & 283.950 & Solid triangle & Black \\
EAH5, Volunteer at a Hungarian environmental NGO & 146.625 & Solid triangle & Black \\
\hline
\end{tabular}

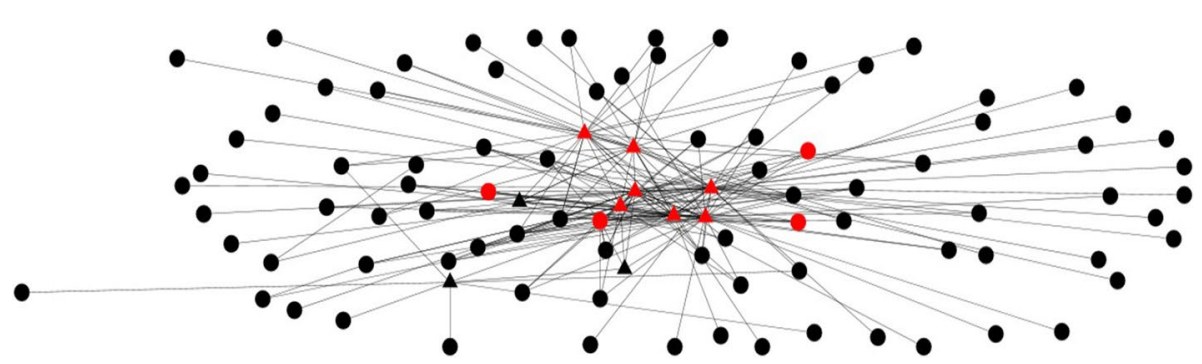

Fig. 2 Sociogram showcasing nodes with high betweenness centrality. Solid triangle-top 10 betweenness centrality. Disk—rest of the nodes. Red—nodes identified as central by the qualitative data. Black-rest of the nodes 
Seven out of the eleven nodes identified through interviewing as central to the network were identified as such also by computing their betweenness centrality. Nodes that appear on the figure as solid triangles are the ten nodes with the highest betweenness centrality. Betweenness centrality for these nodes ranges from 2152.586 to 146.625 (Table 2). The node with the highest betweenness centrality is the assistant of the Member of the European Parliament initiating legislation banning cyanide-based mining at the European level. The other nine are representatives of INGOs, NGOs and social movements, as well as the Hungarian Ambassador to Romania. These actors exercise a monopoly in connecting different sections of the network and they are crucial in keeping alive information and good practice exchanges between the network sections.

The comparative analysis of Tables 1 and 2 shows there is a strong overlap between the network actors with the highest degree and betweenness centrality. The qualitative interviews also indicated these actors are central to the network and part of the 'nerve center.' This is important as it increases the confidence in the findings included in this paper. It also shows there are awareness and acceptance in the network for the central position that hubs occupy. These central network nodes tend to be representatives of INGOs, NGOs and social movements. This is not surprising given that they maintain the connections and mediate the information flow between national segments of the transnational network, local social movements and scientists, as well as stay in touch with the staff of relevant politicians. While findings presented in this section indicate that certain actors are more central to the network, the next section will discuss the factors that led to this.

\section{Explaining the presence of hubs}

The previous section of the paper indicated that the CBN nodes are not equal, that some advocates possess a higher degree and betweenness centrality. They are better connected than other CBN members and as a result they occupy a central position in this network. They keep the network connected and are in a good position to act as brokers. Their centrality is a result of the deliberate choices that the network members made in order to facilitate information exchange, learning and decision-making in the network.

In the case of the $\mathrm{CBN}$, hubs emerged as delegating communication and decision-making tasks to them was found to increase the network efficiency, defined here as achieving a goal or completing a task with minimum resources. The hubs allowed the network to campaign and achieve support for a ban in the European Parliament, despite limited resources. Limited time and financial resources determined certain CBN members to delegate international communication tasks, while concentrating on other aspects of the campaign:

I have not worked for instance with the persons in Bulgaria, but I know that they have achieved certain results. There is no need for me to forge a relationship with them, as somebody else in our group is connected to them (EAR2).

And:

normally the people from Alburnus Major [local social movement] are doing this and we support them, we set up this kind of support structure; it does not make sense to replicate these international communication structures (EAR7).

There was a special interest in not replicating some of the communication work that was already performed in the network. Consequently, the actors that performed these communication tasks became more important in connecting and integrating in the information flow 
network segments based in Romania, Hungary, Bulgaria, Greece and Belgium (particularly in Brussels where the EU institutions are located). The information that members of the network exchanged was related to the regulatory framework applicable to cyanide in their home country, scientific studies on the impact of gold mining and, most importantly, information on their campaigning strategies. One interviewee stated that: 'we engage in information exchange, on what works and what does not work or simply on strategies of communication' (EAR10). The information exchange enabled different groups to learn from the campaign experience of activists in neighboring countries. Substantial amounts of learning on campaigning strategy took place as the campaigning evolved from national campaigns taking place in Romania or Hungary to an EU-wide campaign.

Being involved in the international communication required certain skills and this increased the chances of certain network advocates to emerge as brokers. In the case of the $\mathrm{CBN}$, a good command of English gave certain network members a competitive advantage that allowed them to become brokers as the mother tongues (Romanian, Hungarian, Bulgarian and Greek, etc.) of most of the people involved in the cyanide ban campaigning are very different (EAB2). For instance, the representatives of a local grassroots organization that opposes a cyanide-based mining project in the village of Rosia Montana, Central-West Romania, played an important role in the exchange of information between the Romanian cyanide ban campaign and the groups in the neighboring countries. Brokerage is particularly important in the case of transnational networks where the national and ethnic differences are more likely to make an impact (Kahler 2009b).

As explained in an interview by the representative of a Romanian environmental NGO (EAR11), the people in charge of international information exchange on behalf of the Romanian group became 'the repository of all the connections between the organizations.' Stronger interpersonal relations developed between them and other actors who play the role of international communicators on behalf of groups in Hungary, Bulgaria and Greece. This allowed the representatives of national groups to establish themselves as information brokers within the network. Other members of the national groups are simply aware that those transnational informational connections exist, but they do not play an active role in maintaining them. They receive information by connecting with the members that make up the nerve center (EAR7, EAB3, EAH2). The members of the nerve center have considerable control over the information flows.

In the $\mathrm{CBN}$, brokers do not only intermediate the exchange of information, but they also play a more important role in the decision-making process. According to a member central to the $\mathrm{CBN}$, decisions regarding the international campaign need to be approved only by the members of the closed online group, of the 'nerve center.' To further speed the decision-making process, each member of the group needs to reply within 2 days to the proposals made by another member of the group. Silence is considered as being an affirmative vote: 'if somebody does not say no in 2 days, it means she/he says yes' (EAR1). The existence of the 'nerve center' speeds up the decision-making process. Given this form of centralization, some network members have a more important word to say in the strategies implemented in the international campaign than the peripheral network actors (EAB1, EAG1, EAR10).

CBN hubs benefit from a structurally privileged position, as well as formal recognition in the network. The interviews revealed that the network members are aware that certain network members are more active in networking internationally and they support these actors. The task of acting as network brokers was placed with them by members of the network because they have good English language skills and international experience. Their overall impact on the network is perceived by the other network members as a positive 
one. The presence of hubs indicates that the $\mathrm{CBN}$ is accommodating elements of hierarchy and, consequently, it is a hybrid structure. The CBN fulfills both conditions set by Kahler for hybrid structures (Kahler 2009b, 106) and discussed in more detail in the theoretical section of this paper. Namely, the CBN encompasses nodes that wield power through centrality and accommodates hierarchy among its nodes. The power that central nodes display derives from the position they occupy in the structure of the CBN network. Members of the 'nerve center' have more relational power than peripheral network actors.

\section{Conclusion}

This study is guided by two associated research questions. In answering the first research question 'How are TANs structured?,' this study shows that the CBN displays through its better connected and strategically placed nodes elements of hierarchy making it a hybrid social structure. Findings in this study are in contradiction to the widespread claim in the literature that policy networks are horizontal structures (Peterson 2010) or that TANs entail '(in)voluntary, reciprocal, and horizontal patterns of communication and exchange' (Keck and Sikkink 1998,8). They also challenge the claim that a governance approach implies the horizontal dispersion of authority among a broad number of actors (Hix 1998; Eising and Kohler-Koch 1999; Krahmann 2003a).

When placing its findings in the context of other research on TANs, the case study confirms emerging assumptions regarding hierarchy in TANs developed in the literature, such as the work of Lake and Wong (2009) and Carpenter (2011). For instance, that TANs function "not as flat, distributed networks but as scale-free networks in which a small number of major "hubs" dominate, and pathways between peripheral nodes are dependent on these hubs' (Carpenter 2011, 73). The paper shows that such influential hubs exist also in environmental networks, in similar ways in which they exist in terrorist networks (Carley 2006; Enders and Su 2007) or state networks (Hafner-Burton et al. 2009).

Hubs (representatives of NGOs, INGOs and some leaders of social movements) are central to the network. This is consistent with similar findings in the literature according to which NGOs often play a central role in networks by introducing: 'new ideas, providing information, and lobbying for policy changes' (Keck and Sikkink 1998, 9). Centrally positioned actors have been referred to as being the network 'brokers' and played an important role in keeping alive the connections between more specific groups of network actors (social movements, scientists and politicians) and different network segments. There are five such segments: a Romanian, a Hungarian, a Bulgarian, a Greek and a Brussels-based network segment. The presence of these segments originating mainly in the CEE is not surprising given that the CBN advocated for the ban of cyanide-based mining technologies in the EU hoping in this way to reduce the chances of cyanide spills in the CEE, spills such as the one that took place at Baia Mare in 2000. CBN hoped that by preventing water and environmental pollution to contribute to the implementation of regional environmental agreements (the Convention on Cooperation for the Protection and Sustainable Use of the River Danube), as well as global agreements (the Convention on Biological Diversity). In constructing the argument for an EU ban, the network relied on the precautionary principle, a core principle of the Convention on Biological Diversity.

In answering the second research question 'What relation is established between the TANs' structure and their efficiency?', the research findings show hierarchy is integrated for the network to perform easier certain functions related to information exchange and 
taking decisions in a reasonable timeframe. Networks are often praised for the absence of hierarchy and for their flatness (Watts 2003; Powell 1990); however, the findings on this case raise doubts regarding the advantages that flatness brings to a network.

The potential weaknesses of flat transnational networks have been less studied than their advantages. As a result, often researchers have emphasized the capacity of networks as horizontal structures to foster communication and learning (Powell 1990; Baker and Faulkner 1993; Podolny and Page 1998; Kenney 2006; Kenney et al. 2013). The findings of this study indicate that network members are willing to delegate the communication and decision-making tasks and in this way generate hierarchy. Delegating tasks allows the network members to remain efficient in their overall activity and the CBN to operate well, despite limited human resources. Additional empirical and quantitative studies need to be conducted to refine our understanding of the way transnational networks, in general, and, particularly, environmental TANs are structured and to assess what degree of hierarchy is optimal, but this study constitutes a good starting point.

Although questioned as being able to generate new insights on TANs (Keck and Sikkink 1998), social network analysis can help to better analyze and map the structure of transnational networks, as this paper showed. This method can generate quantitative evidence that reinforces and complements the initial qualitative findings. Social network analysis employed in longitudinal studies can further increase our knowledge on the way the structure of networks changes in time and hopefully will be employed for this purpose in future research.

Open Access This article is licensed under a Creative Commons Attribution 4.0 International License, which permits use, sharing, adaptation, distribution and reproduction in any medium or format, as long as you give appropriate credit to the original author(s) and the source, provide a link to the Creative Commons licence, and indicate if changes were made. The images or other third party material in this article are included in the article's Creative Commons licence, unless indicated otherwise in a credit line to the material. If material is not included in the article's Creative Commons licence and your intended use is not permitted by statutory regulation or exceeds the permitted use, you will need to obtain permission directly from the copyright holder. To view a copy of this licence, visit http://creativecommons.org/licenses/by/4.0/.

\section{Appendix}

Interviews with network members referenced in the article (includes only interviews of people explicitly referenced in the article, although forty-five people were interviewed for this study):

\begin{tabular}{lll}
\hline $\begin{array}{l}\text { Abbrev. in the } \\
\text { text (if appli- } \\
\text { cable) }\end{array}$ & $\begin{array}{l}\text { Interviewee position/affiliation (Some } \\
\text { individuals have multiple affiliations, } \\
\text { declared at the moment of the interview; } \\
\text { they were referenced in the study with } \\
\text { their primary affiliation.) }\end{array}$ & Date/place of the interview \\
\hline EAR1 & $\begin{array}{l}\text { The President of the Romanian Academy } \\
\text { Representative of a Romanian social } \\
\text { movement }\end{array}$ & 9 Dec. 2010, Bucharest, Romania \\
EAR2 & $\begin{array}{l}\text { Representative of a Romanian environ- } \\
\text { mental NGO }\end{array}$ & 2 Sep. 2010, Cluj-Napoca, Romania \\
EAR3 & $\begin{array}{l}\text { Representative of a Romanian environ- } \\
\text { mental NGO }\end{array}$ & 3 Sep. 2010, Cluj-Napoca, Romania \\
\hline
\end{tabular}




\begin{tabular}{ll}
\hline Abbrev. in the & $\begin{array}{l}\text { Interviewee position/affiliation (Some } \\
\text { text (if appli- } \\
\text { individuals have multiple affiliations, } \\
\text { cable) }\end{array}$ \\
& $\begin{array}{l}\text { declared at the moment of the interview; } \\
\text { they were referenced in the study with } \\
\text { their primary affiliation.) }\end{array}$
\end{tabular}

\begin{tabular}{|c|c|c|}
\hline EAR6 & $\begin{array}{l}\text { Representative of a Romanian environ- } \\
\text { mental NGO, Volunteer with a Roma- } \\
\text { nian social movement }\end{array}$ & 6 Dec. 2010, Bucharest, Romania \\
\hline EAR7 & $\begin{array}{l}\text { Representative of a Romanian environ- } \\
\text { mental NGO }\end{array}$ & 14 Dec. 2010, Bucharest, Romania \\
\hline EAR8 & $\begin{array}{l}\text { Representative of a Romanian environ- } \\
\text { mental NGO }\end{array}$ & 7 Dec. 2010, Bucharest, Romania \\
\hline EAR10 & $\begin{array}{l}\text { Representative of a Romanian NGO, } \\
\text { Volunteer with a Romanian social } \\
\text { movement }\end{array}$ & 11 Dec. 2010, Bucharest, Romania \\
\hline EAR11 & $\begin{array}{l}\text { Representative of a Romanian environ- } \\
\text { mental NGO, Volunteer with a Roma- } \\
\text { nian social movement }\end{array}$ & 3 Sep. 2010, Cluj-Napoca, Romania \\
\hline EAH1 & $\begin{array}{l}\text { Representative of 'Friends of the Earth' } \\
\text { Hungary }\end{array}$ & 27 Sep. 2010, Budapest, Hungary \\
\hline EAH2 & Representative of 'Bankwatch' Hungary & 28 Sep. 2010, Budapest, Hungary \\
\hline EAH3 & Representative of 'Greenpeace' Hungary & 28 Sep. 2011, Budapest, Hungary \\
\hline EAH4 & $\begin{array}{l}\text { Member of the Green Hungarian Party } \\
\text { LMP, Member of the Hungarian Parlia- } \\
\text { ment }\end{array}$ & 27 Sep. 2010, Budapest, Hungary \\
\hline EAH5 & $\begin{array}{l}\text { Volunteer at a Hungarian environmental } \\
\text { NGO }\end{array}$ & 16 Dec. 2010, Budapest, Hungary \\
\hline EAB1 & $\begin{array}{l}\text { Representative of a Bulgarian NGO, affili- } \\
\text { ated with Central and Eastern Europe } \\
\text { 'Bankwatch' Network }\end{array}$ & $\begin{array}{l}11 \text { Feb. 2011, Cambridge, UK/Sofia, } \\
\text { Bulgaria }\end{array}$ \\
\hline EAB2 & $\begin{array}{l}\text { Representative of Central and Eastern } \\
\text { Europe 'Bankwatch' Network }\end{array}$ & $\begin{array}{l}\text { 16 Feb. 2011, Cambridge, UK/Blageovgrad, } \\
\text { Bulgaria }\end{array}$ \\
\hline EAB3 & $\begin{array}{l}\text { Representative of a Bulgarian environ- } \\
\text { mental NGO }\end{array}$ & $\begin{array}{l}3 \text { April 2011, Cambridge, UK/Plovdiv, } \\
\text { Bulgaria }\end{array}$ \\
\hline EAG1 & $\begin{array}{l}\text { Representative of a Greek NGO, } \\
\text { representative of a Greek local social } \\
\text { movement }\end{array}$ & $\begin{array}{l}10 \text { Feb 2010, Cambridge, UK/Olympias, } \\
\text { Greece }\end{array}$ \\
\hline EAG2 & $\begin{array}{l}\text { Lecturer at 'Aristotle' University of Thes- } \\
\text { saloniki, volunteer with a Greek local } \\
\text { social movement }\end{array}$ & $\begin{array}{l}24 \text { Feb 2010, Cambridge, UK/Thessaloniki, } \\
\text { Greece }\end{array}$ \\
\hline EAG3 & $\begin{array}{l}\text { Lecturer at 'Aristotle' University of Thes- } \\
\text { saloniki }\end{array}$ & $\begin{array}{l}8 \text { April 2011, Cambridge, UK/Thessaloniki, } \\
\text { Greece }\end{array}$ \\
\hline MEPA1 & Assistant to a Hungarian MEP & 17 Dec. 2010, Budapest, Hungary \\
\hline MEPA3 & Assistant to a Greek MEP & 2 March, Brussels, Belgium \\
\hline
\end{tabular}

\section{References}

Ader, J., Seeber, R., Skylakakis, T., et al. (2010). Joint motion for a resolution on a general ban on the use of cyanide mining technologies in the European Union. https://www.europarl.europa.eu/sides/getDo c.do?pubRef=-//EP//NONSGML+MOTION+P7-RC-2010-0238+0+DOC+PDF+V0//EN\&langu age $=$ EN. Accessed August 15, 2019. 
Baker, W. E., \& Faulkner, R. R. (1993). The social organization of conspiracy: Illegal networks in the heavy electrical equipment industry. American Sociological Review, 58(6), 837-860.

Bank of England. (2011). End of year gold price against US\$. Bank of England Report, accessible http:// www.bankofengland.co.uk/mfsd/iadb/fromshowcolumns.asp. Accessed April 15, 2011.

Betsill, M. M., \& Bulkeley, H. (2004). Transnational networks and global environmental governance: The cities for climate protection program. International Studies Quarterly, 48(2), 471-493.

Bob, C. (2005). The marketing of rebellion. Cambridge: Cambridge University Press.

Brubaker, R., \& Cooper, F. (2000). Beyond “identity". Theory and Society, 29(1), 1-47.

Burnham, P., Lutz, K. G., Grant, W., \& Layton-Henry, Z. (2008). Research methods in politics (2nd ed.). Houndmills: Palgrave Macmillan.

Buza, M., Dimen, L., Pop, G., \& Turnock, D. (2001). Environmental protection in the Apuseni Mountains: The role of environmental non-governmental organizations (ENGOs). GeoJournal, 55(2), 631-653.

Buzogány, A. (2009). Romania: Environmental governance-Form without substance. In T. Börzel (Ed.), Coping with accession to the European Union. New modes of environmental governance (pp. 169192). Houdmills: MacMillan.

Carley, K. (2006). Destabilization of covert networks. Computational and Mathematical Organization Theory, 12(1), 51-66.

Carpenter, C. (2011). Vetting the advocacy agenda: Network centrality and the paradox of weapons norms. International Organization, 65(1), 69-102.

Carpenter, C., \& Jose, B. (2012). Transnational issue networks in real and virtual space: The case of women, peace and security. Global Networks, 12(4), 525-543.

Castells, M. (1996). The rise of the network society, vol. I: The information age: economy, society and culture. Malden, MA: Blackwell.

Cox, T., \& Gallai, S. (2014). Civil society and policy actors in post-communist Hungary: Linkages and contexts. Perspectives on European Politics and Society, 15(1), 51-67.

Damigos, D., \& Kaliampakos, D. (2006). The "battle of gold" under the light of green economics: A case study from Greece. Environmental Geology, 50(2), 202-218.

Diani, M. (2003). Leaders or brokers? Positions and influence in social movement networks. In M. Diani \& D. McAdam (Eds.), Social movements and networks: Relational approaches to collective action (pp. 105-122). Oxford: Oxford University Press.

Eilstrup-Sangiovanni, M. (2009). Varieties of cooperation: government networks in international security. In M. Kahler (Ed.), Networked politics: Agency, power and governance (pp. 194-226). Ithaca: Cornell University Press.

Eilstrup-Sangiovanni, M., \& Jones, C. (2008). Assessing the dangers of illicit networks: Why al-Qaeda may be less threatening than many think. International Security, 33(2), 7-44.

Eising, R., \& Kohler-Koch, B. (1999). Introduction: network governance in the European Union. In B. Kohler-Koch \& R. Eising (Eds.), The transformation of governance in the European Union (pp. 1-12). London: Routledge.

Ekiert, G., \& Kubik, J. (2014). Myths and realities of civil society. Journal of Democracy, 25(1), 46-58.

Emirbayer, M., \& Goodwin, J. (1994). Network analysis, culture, and the problem of agency. American Journal of Sociology, 99(6), 1411-1454.

Enders, W., \& Jindapon, P. (2009). Network externalities and the structure of terror networks. Journal of Conflict Resolution, 54(2), 262-280.

Enders, W., \& Su, X. (2007). Rational terrorists and optimal network structure. Journal of Conflict Resolution, 51(1), 33-57.

Fontana, A., \& Frey, J. H. (1994). Interviewing: The art of science. In N. K. Denzin \& Y. S. Lincoln (Eds.), Handbook of qualitative research (pp. 361-376). Thousand Oaks: Sage.

Freeman, L. C. (1979). Centrality in social networks: conceptual clarification. Social Networks, 1(3), $215-239$.

Gillham, B. (2005). Research interviewing: the range of techniques. Maidenhead: Open University Press.

Goddard, S. (2009). Brokering change: Networks and entrepreneurs in International Politics. International Theory, 1(2), 249-281.

Goodman, L. A. (1961). Snowball sampling. Annals of Mathematical Statistics, 32(2), 148-170.

Gulati, R., Dialdin, D. A., \& Wang, L. (2002). Organizational networks. In J. A. C. Baum (Ed.), The blackwell companion to organizations (pp. 281-303). Oxford: Blackwell.

Gusterson, H. (2008). Ethnographic research. In A. Klotz \& D. Prakash (Eds.), Qualitative methods in international relations: A pluralist guide (pp. 93-113). Houndmills: Palgrave Macmillan.

Hafner-Burton, E., Kahler, M., \& Montgomery, A. H. (2009). Network analysis for international relations. International Organization, 63(3), 559-592. 
Hamel, G. (1991). Competition for competence and inter-partner learning within international strategic alliances. Strategic Management Journal, 12(S1), 83-103.

Held, D., McGrew, A., Goldblatt, D., \& Perraton, J. (1999). Global transformations. Cambridge: Polity.

Helfstein, S. (2009). Governance of terror: New institutionalism and the evolution of terrorist organizations. Public Administration Review, 69(4), 727-739.

Hix, S. (1998). The study of the European Union II: The "new governance" agenda and its rival. Journal of European Public Policy, 5(1), 38-65.

Howard, M. M. (2003). The weakness of civil society in post-communist Europe. Cambridge: Cambridge University Press.

John, P., \& Cole, A. (1998). Sociometric mapping techniques and the comparison of policy networks: economic decision making in Leeds and Lille. In D. Marsh (Ed.), Comparing policy networks (pp. 132146). Buckingham: Open University Press.

Kahler, M. (2009a). Networked politics: Agency, power and governance. In M. Kahler (Ed.), Networked politics: Agency, power and governance (pp. 1-20). Ithaca: Cornell University Press.

Kahler, M. (2009b). Collective action and clandestine networks: the case of al Qaeda. In M. Kahler (Ed.), Networked politics: Agency, power and governance (pp. 103-124). Ithaca: Cornell University Press.

Keck, M., \& Sikkink, K. (1998). Activists beyond borders: advocacy networks in international politics. Ithaca: Cornell University Press.

Kenney, M. (2006). From Pablo to Osama. Trafficking and terrorist networks, government bureaucracies, and competitive adaptation. University Park, PA: Penn State University Press.

Kenney, M. (2007). The architecture of drug trafficking: network forms of organization in the Colombian cocaine trade. Global Crime, 8(3), 233-259.

Kenney, M. (2009). Turning to the "Dark Side'": coordination, exchange and learning in criminal networks. In M. Kahler (Ed.), Networked politics: Agency, power and governance (pp. 79-102). Ithaca: Cornell University Press.

Kenney, M., Horgan, J., Horne, C., et al. (2013). Organisational adaptation in an activist network: social networks, leadership, and change in al-Muhajiroun. Applied Ergonomics, 44(5), 739-747.

Krahmann, E. (2003a). Conceptualizing security governance. Cooperation and Conflict, 38(5), 5-26.

Krahmann, E. (2003b). Multilevel networks in European foreign policy. Aldershot: Ashgate.

Lake, D., \& Wong, W. (2009). The politics of networks: interests, power and human rights norms. In M. Kahler (Ed.), Networked politics: Agency, power and governance (pp. 127-150). Ithaca: Cornell University Press.

Levitt, B., \& March, J. (1988). Organizational learning. Annual Review of Sociology, 14, 319-340.

Maoz, Z. (2012). How network analysis can inform the study of International Relations. Conflict Management and Peace Science, 29(3), 247-256.

Mason, M. (2001). Transnational environmental obligations: locating new spaces of accountability in a post-Westphalian global order. Transactions of the Institute of British Geographers, New Series, 26(4), 407-429.

Mérand, F., Hofmann, S., \& Irondelle, B. (2011). Governance and state power: A network analysis of European security. Journal of Common Market Studies, 49(1), 121-147.

Parau, C.-E. (2009). Impaling Dracula: How EU accession empowered civil society in Romania. West European Politics, 32(1), 119-141.

Peterson, J. (2010). Policy networks. In A. Wiener \& T. Diez (Eds.), European integration theory (2nd ed., pp. 105-124). Oxford: Oxford University Press.

Podolny, J. M., \& Page, K. L. (1998). Network form of organization. Annual Review of Sociology, 24, $57-76$.

Powell, W. W. (1990). Neither market nor hierarchy: network forms of organization. Research in Organizational Behavior, 12, 295-336.

Powell, W. W., \& Brantley, P. (1992). Competitive cooperation in biotechnology: learning through networks. In N. Nohria \& R. G. Eccles (Eds.), Networks and organizations: Structure, form and action (pp. 366394). Boston: Harvard Business School Press.

Price, R. (1998). Reversing the gun sights: Transnational civil society targets land mines. International Organization, 52(3), 613-644.

Richards, J. (2005). Rosia Montana gold controversy. Mining Environmental Management, 5-13.

Rodrigues, M. G. M. (2004). Global environmentalism and local politics: Transnational advocacy networks in Brazil, Ecuador and India. New York: State University of New York Press.

Romantan, A. (2006). Fuzzy Europeanization: The role of the EU in civic opposition to gold mining in Romania. Paper Presented to the 2006 Council of European Studies meeting in Chicago, unpublished paper. 
Royo, A. G. (2000). The Philippines: Against the people's wishes, the Mt. Apo story. In J. A. Fox \& L. D. Brown (Eds.), The struggle for accountability: The World Bank, NGOs and grassroots movements (pp. 151-179). Cambridge, MA: MIT Press.

Rumansara, A. (2000). 'Indonesia: The struggle of the people of Kedung Ombo. In J. A. Fox \& D. L. Brown (Eds.), The struggle for accountability: The World Bank, NGOs and grassroots movements (pp. 123149). Cambridge, MA: MIT Press.

The European Commission. (2010). Answer given by Mr. Potočnik on behalf of the Commission', Parliamentary Questions. 23.06.2010, P7_RE(2010)3589.

The European Parliament. (2010). European Parliament resolution of 5 May 2010 on a general ban on the use of cyanide mining technologies in the European Union. 5.05.2010, P7_TA(2010)0145.

The United Nations Environmental Programme/The United Nations Office for the Coordination of Humanitarian Affairs (OCHA) Assessment Mission. (2000). Cyanide Spill at Baia Mare, Romania. http:// www.reliefweb.int/ocha_ol/programs/response/unep/rombaiamare.html. Accessed May 10, 2010.

Thompson, G. (2003). Between hierarchies and markets: The logic of network forms of organization. Oxford: Oxford University Press.

Torsello, D. (2016). The new environmentalism? Civil society and corruption in the enlarged EU. London: Routledge.

Uzzi, B. (1997). Social structure and competition in interfirm networks: The paradox of embeddedness. Administrative Science Quarterly, 42, 35-67.

Wasserman, S., \& Faust, K. (1994). Social network analysis: Methods and applications. New York: Cambridge University Press.

Watts, D. J. (2003). Six degrees: The science of a connected age. London: Heinemann.

Welch, S. (2004). Democracy without civil society? International Studies Review, 6(2), 306-308.

Witte, J. M., Reinicke, W. H., \& Benner, T. (2005). Beyond multilateralism: Global public policy networks. In A. Pfaller \& M. Lerch (Eds.), Challenges of globalization (pp. 109-130). New Brunswick: Transaction Publishers.

Yanacopulos, H. (2009). Cutting the diamond: Networking economic justice. In M. Kahler (Ed.), Networked politics: Agency, power and governance (pp. 67-78). Ithaca: Cornell University Press.

Zanini, M., \& Edwards, S. J. A. (2001). The networking of terror in the information age. In J. Arquilla \& D. Ronfeldt (Eds.), Networks and netwars: The future of terror, crime and militancy (pp. 29-60). Santa Monica, CA: RAND.

Publisher's Note Springer Nature remains neutral with regard to jurisdictional claims in published maps and institutional affiliations. 